\title{
An Analysis of Economic Feasibility on The Hybrid Maize Farming of The Bima 20 URI on Several Types of Land in East Nusa Tenggara
}

\author{
Helena da Silva ${ }^{1, *}$ and Yohanes L. Seran ${ }^{1}$ \\ Agricultural Technology Assessment Center (BPTP) of East Nusa Tenggara
}

\begin{abstract}
Evaluation on feasibility of seed is carried out at the breeding level in Nagekeo Regency during 1 ( one ) year (2015) and the result of F1 is evaluated in the agro-ecosystem of wet rice field ( Nagekeo District), dry land ( Kupang district ) and land of Ahuklean (Malaka district ). The results shows that: a) the average productivity of the F1 Bima 20 URI seeds is $3,200 \mathrm{~kg} / \mathrm{ha}$, however, if the price of seed was IDR $27,500 / \mathrm{kg}$, the breeder will get a profit of IDR 20,496,000. b) Corn productivity of the F1 Bima 20 URI which was planted in agro-ecosystem of irrigated wet rice field, dry land and land of ahulean respectively 6.75 tons/ha, 5 tons/ha and 3 ton/ha with a profit of each respectively of IDR 22,220.00 and IDR $15,220,000$, IDR $8,850.00$; c) The value of $\mathrm{R} / \mathrm{C}$ ratio of the seed breeder of the F1 Bima URI 20 was of 2.63 and the value of $\mathrm{R} / \mathrm{C}$ ratio of the hybrid Bima URI 20 in various agroecosystems of $4.65,3.18$ and 2.81 . Thus, the seeding and development of the hybrid corn Bima URI 20 in NTT is reasonably to be carried out.
\end{abstract}

\section{Introduction}

Corn is the staple food for most of the people of East Nusa Tenggara (NTT). The wide of planting area of hybrid maize in NTT for the last 4 years (20014-20017) has increased every year, such as $36.718,61,712,112,026$ and 150,223 [1]. Corn production is entirely for consumption in NTT and is not for sale outside of the region because the amount of corn production is estimated only to fulfil $60 \%$ of the total demand for corn in NTT.

The trend of increasing domestic demand for corn has encouraged efforts to increase domestic maize productivity. This increase in productivity was mostly dominated by hybrid maize which has excellent characteristic compared to local maize [2].

With the highly demand for corn seeds in NTT, the availability of source seeds to produce seeds labeled with the below class needs to be held continuously. Apart from freeseeded seeds, the need for hybrid seeds also continues to increase. On the other hand,

* Corresponding author: helena dasilva73@yahoo.com 
providers of hybrid seeds are generally private parties, because there is no parent stock seed producer in NTT.

Socio-economic problems are also found in the field, namely the level of enthusiasm for farmers is still low because the price of maize is very variation and uncertain [3]. Furthermore, [4] reports that the low productivity of maize in several national production centers is due to the fact that there are still many farmers who plant local varieties and old superior varieties whose seeds have been genetically degraded and have not been purified. The seeds planted are seeds taken from previous plantings so that their production capacity continues to decline [5].

The problems of increasing production, productivity and quality of crop products such as the availability of certified seeds and propagation of plant seeds are still limited, [6] the number of aid seeds that do not grow, the impact of climate change on crop production which causes farmers in East Nusa Tenggara to experience the risk of crop failure, these factors cause the area of planting and production which fluctuates every year. Other obstacles faced, especially in terms of production costs continue to increase. The selling price is uncertain at the middleman level. However, until now the farming is still running. In order to reduce the gap in the supply of free-seeded seeds and hybrid maize seeds and to anticipate the price of hybrid maize seeds that was too high, so efforts to provide both freeseed and parent stock seeds were necessarily conducted in NTT.

Based on the above matters, the researcher is interested in conducting a study on "Analysis of the Feasibility of Hybrid Corn Farming in several Land Agro-ecosystems in NTT".

\section{Methodology}

This research was conducted in several regions in NTT. The F1 Hybrid Corn Bima 20 URI as results of seeding in 2008 which was carried out in the experimental area in Naibonat. The tested on the three types of agro-ecosystem in NTT such as : a). agro ecosystem land of wet rice fields where corn is planted after rice harvest in June to October, 2016 in the land of farmers in Oesao village, District of Kupang Timur, Kupang Regency; b) . Agro-ecosystem of dry land in the new area by the way of TOT (Without Processing of Land) in Danga village, Sub District of Danga, Nagekeo Regency in AprilAugust 2016 , and c) agro-ecosystem of dry land without irrigation, without rainy water by means of "ahuklean" (dig deeper ) in July-November 2016 in village of Besikama, Malaka Barat, Regency of Belu. The data obtained are the input data as the output of farming activity within a year, namely 2016 . The analysis of income is by using the formulas:

$$
\mathrm{I}=\sum(y . P y)-\sum(X i . P x i)
$$

Remarks:

$$
\begin{array}{ll}
\mathrm{I} & =\text { Income }(\mathrm{IDR} / \mathrm{ha}) \\
\mathrm{Y} & =\text { Output }(\mathrm{kg}) \\
\mathrm{Pxi} & =\text { Input Price (IDR) } \\
\mathrm{Py} & =\text { output (IDR) } \\
\mathrm{Xi} & =\text { input }(\mathrm{i}=1,2,3 \ldots \mathrm{n})
\end{array}
$$

The analysis is done by using analysis of partial budgets. The Indicator analysis that is used is the $\mathrm{R} / \mathrm{C}$ ratio (Return Cost Ratio. $\mathrm{R} / \mathrm{C}$ ratio is the ratio (ratio) between revenue and costs. Mathematically, this can be written as follows: 


$$
\begin{gathered}
a: \frac{R}{C} \\
\mathrm{R}=\mathrm{Py} \cdot \mathrm{Y} \\
\mathrm{C}=\mathrm{FC}+\mathrm{VC} \\
\mathrm{a}=\{(\mathrm{Py} . \mathrm{Y}) /(\mathrm{FC}+\mathrm{VC})\}
\end{gathered}
$$

Remarks:

$$
\begin{array}{ll}
\mathrm{R} & =\text { Revenue } \\
\mathrm{C} & =\text { Cost } \\
\mathrm{Py} & =\text { Price of output } \\
\mathrm{Y} & =\text { Output } \\
\mathrm{FC} & =\text { Fixed costs (fixed cost) } \\
\mathrm{VC} & =\text { Costs are not fixed (variable cost) }
\end{array}
$$

If : $a>1$ it is said to be feasible,

$a<1$ then it is said to be inappropriate and

$\mathrm{a}=1$ then it is said to break even (neither profit nor loss)

Meanwhile the analysis of income contribution is obtained by comparing the income of commodities with total income of farming activities within one year multiplied by $100 \%$, namely by the formula:

$$
\frac{P n}{T p} \times 100 \%
$$

Remarks:

Pn $=$ commodity income $\mathrm{n}$

$\mathrm{TP}=$ Total Income of Farming activities

\section{Results and Discussion}

\subsection{The analysis of feasibility on production of hybrid corn in NTT}

Based on the results of the analysis on farming activity of corn production of the F1 Bima URI 20 with a wide area of the planting of one (1) hectare can be achieved the row income namely IDR $33,000,000$ - while the results of the sale is $1,200 \mathrm{~kg}$ with the price per $\mathrm{kg}$ of IDR 27,500, meanwhile from the results of the production of F1 Bima 20 URI of the farmer/breeder will get a profit of IDR 20,496,000.

The result of the feasibility analysis of the F1 Bima URI 20 on production obtained the value of $\mathrm{R} / \mathrm{C}$ ratio of 263 . The value of $\mathrm{R} / \mathrm{C}$ ratio that is stated that the commodity of Hybrid corn Bima 20 URI is recommended reasonable to be cultivated in the region of NTT. 
Table 1. Analysis of feasibility of seeding production of the hybrid corn of the Bima 20 URI in NTT, in annually budget 2016

\begin{tabular}{|c|c|c|c|c|c|}
\hline No & Description & Unit & Volume & Unit price & Total \\
\hline \multirow[t]{9}{*}{$\mathrm{A}$} & \multicolumn{5}{|c|}{ Cost of Production Facilities } \\
\hline & Seed & $\mathrm{Kg}$ & 20 & 236,000 & $4,740,000$ \\
\hline & Fertilizer of Ponskah & Sack & 8 & 160,000 & $1,280,000$ \\
\hline & Fertilizer of Urea & Sack & 4 & 85,000 & 340,000 \\
\hline & Insecticide & $\mathrm{Kg}$ & 4 & 41,000 & 164,000 \\
\hline & Fungicide & Liter & 2 & 80,000 & 160,000 \\
\hline & Plastic Package & $\mathrm{Kg}$ & 3 & 30,000 & 90,000 \\
\hline & Labeling & Sheet & 1,500 & 1,000 & $1,500,000$ \\
\hline & \multicolumn{4}{|l|}{ Total Cost of A } & $8,245,000$ \\
\hline \multirow[t]{12}{*}{ B } & \multicolumn{5}{|l|}{ Cost of Labor } \\
\hline & Planting & $\mathrm{OH}$ & 20 & 25,000 & 500,000 \\
\hline & Cultivated & $\mathrm{OH}$ & 50 & 25,000 & $1,250,000$ \\
\hline & Spread Fertilizer & $\mathrm{OH}$ & 20 & 25,000 & 500,000 \\
\hline & Data selling & $\mathrm{OH}$ & 25 & 25,000 & 625,000 \\
\hline & Rouging & $\mathrm{OH}$ & 5 & 25,000 & 125,000 \\
\hline & Spray & $\mathrm{OH}$ & 10 & 25,000 & 250,000 \\
\hline & Harvest & $\mathrm{OH}$ & 5 & 25,000 & 125,000 \\
\hline & Threshing & $\mathrm{OH}$ & 20 & 25,000 & 500,000 \\
\hline & Drying & $\mathrm{OH}$ & 5 & 25,000 & 125,000 \\
\hline & Package & $\mathrm{OH}$ & 10 & 25,000 & 250,000 \\
\hline & \multicolumn{4}{|l|}{ Total of B } & $4,250,000$ \\
\hline \multicolumn{5}{|c|}{ Total of A + B } & $12,504,000$ \\
\hline \multicolumn{2}{|c|}{ Corn Production } & $\mathrm{Kg}$ & 1,200 & 27,500 & $33,000,000$ \\
\hline \multicolumn{2}{|c|}{ Income } & & & & $20,496,000$ \\
\hline \multicolumn{2}{|c|}{ R/C Ratio } & & & & 2.63 \\
\hline \multicolumn{2}{|c|}{ B/C Ratio } & & & & 1.63 \\
\hline
\end{tabular}

Source: Primary Data

\subsection{The Analysis of Farming Feasibility on Hybrid Corn of Bima URI 20}

Data on the table above shows that cost variable which consist of seeds, fertilizer, insecticide and labor to produce the Bima 20 URI such as IDR 2,030,000/ha, while fix cost such as cost of labor, rental machine, rental land namely IDR 2,750,000/ha. Total of cost for efforts of hybrid corn in dry land in Kupang Regency of IDR 4,780,000/ha per season. Production of hybrid corn of the Bima 20 URI of $6,750 \mathrm{~kg}$, dry loosen beans with the price of IDR 4,000/kg that gained from revenue of IDR 27,000,000, so it can be achieved income IDR 22,220,000 with R/C 4,649.

Corn production is determined by the use of inputs, including seeds, fertilizers, pesticides and labor and cropping systems. According to [7], costs include a measurement of the value of resources that must be sacrificed as a result of activities aimed at seeking profit. 
Table 2. The Analysis of Farming Feasibility on Hybrid Corn of Bima URI 20 on Agro-ecosystem of wet rice field in NTT.

\begin{tabular}{|c|c|c|c|c|c|}
\hline No & Description & Unit & Volume & Unit price & Total \\
\hline \multirow[t]{7}{*}{ A } & \multicolumn{5}{|c|}{ Cost of Production Facilities } \\
\hline & Seed & $\mathrm{Kg}$ & 20 & 27,500 & 550,000 \\
\hline & $\begin{array}{l}\text { Fertilizer of } \\
\text { Ponskah }\end{array}$ & Sack & 6 & 115,000 & 690,000 \\
\hline & fertilizer of Urea & Sack & 2 & 95,000 & 190,000 \\
\hline & Insecticide & Package & 4 & 50,000 & 200,000 \\
\hline & Fungicide & Liter & 5 & 80,000 & 400,000 \\
\hline & Total Cost of A & & & & $2,030,000$ \\
\hline \multirow[t]{7}{*}{$\mathrm{B}$} & \multicolumn{5}{|l|}{ Cost of Labor } \\
\hline & Planting & $\mathrm{OH}$ & 10 & 50,000 & 500,000 \\
\hline & Look after & $\mathrm{OH}$ & 20 & 50,000 & $1,000,000$ \\
\hline & Fertilizing & $\mathrm{OH}$ & 10 & 50,000 & 500,000 \\
\hline & Harvest & $\mathrm{OH}$ & 5 & 50,000 & 250,000 \\
\hline & Drop off & $\mathrm{OH}$ & 10 & 50,000 & 500,000 \\
\hline & \multicolumn{4}{|l|}{ Total of B } & $2,750,000$ \\
\hline \multicolumn{5}{|c|}{ Total of $\mathrm{A}+\mathrm{B}$} & $4,780,000$ \\
\hline \multicolumn{2}{|c|}{ Corn Production } & $\mathrm{Kg}$ & 6,750 & 4,000 & $27,000,000$ \\
\hline \multicolumn{2}{|c|}{ Income } & & & & $22,220,000$ \\
\hline \multicolumn{2}{|c|}{ R/C Ratio } & & & & 4,649 \\
\hline
\end{tabular}

Table 3. The Analysis of Farming Feasibility on Hybrid Corn of the Bima URI 20 on Agroecosystem of Dry Land.

\begin{tabular}{|c|c|c|c|c|c|}
\hline No & Description & Unit & Volume & Unit price & Total \\
\hline \multirow[t]{7}{*}{$\mathrm{A}$} & \multicolumn{5}{|c|}{ Cost of Production Facilities } \\
\hline & Seed & $\mathrm{Kg}$ & 20 & 27,500 & 550,000 \\
\hline & Fertilizer of Ponskah & Sack & 6 & 115,000 & 690,000 \\
\hline & fertilizer of Urea & Sack & 2 & 95,000 & 190,000 \\
\hline & Insecticide & Package & 4 & 50,000 & 200,000 \\
\hline & Fungicide & Liter & 5 & 80,000 & 400,000 \\
\hline & \multicolumn{4}{|l|}{ Total Cost of A } & $2,030,000$ \\
\hline \multirow[t]{7}{*}{$\mathrm{B}$} & Cost of Labor & & & & \\
\hline & Planting & $\mathrm{OH}$ & 10 & 50,000 & 500,000 \\
\hline & Look after & $\mathrm{OH}$ & 20 & 50,000 & $1,000,000$ \\
\hline & Fertilizing & $\mathrm{OH}$ & 10 & 50,000 & 500,000 \\
\hline & Harvest & $\mathrm{OH}$ & 5 & 50,000 & 250,000 \\
\hline & Drop off & $\mathrm{OH}$ & 10 & 50,000 & 500,000 \\
\hline & \multicolumn{4}{|l|}{ Total of B } & $2,750,000$ \\
\hline \multicolumn{2}{|c|}{ Total of $A+B$} & & & & $4,780,000$ \\
\hline \multicolumn{2}{|c|}{ Corn Production } & $\mathrm{Kg}$ & 5.000 & 4,000 & $20,000,000$ \\
\hline \multicolumn{2}{|c|}{ Income } & & & & $15,220,000$ \\
\hline \multicolumn{2}{|c|}{$\mathrm{R} / \mathrm{C}$ Ratio } & & & & 3,184 \\
\hline
\end{tabular}


Table 4. The Analysis of Farming Feasibility on Hybrid Corn of the Bima URI 20 on agroecosystem of dry land with Model of Ahuklean in NTT.

\begin{tabular}{|c|c|c|c|c|c|}
\hline No & Description & Unit & Volume & Unit price & Total \\
\hline \multirow[t]{5}{*}{$\mathrm{A}$} & \multicolumn{5}{|c|}{ Cost of Production Facilities } \\
\hline & Seeds & $\mathrm{Kg}$ & 20 & 27,500 & 550,000 \\
\hline & Insecticide & Package & 4 & 50,000 & 200,000 \\
\hline & Fungicide & Liter & 5 & 80,000 & 400,000 \\
\hline & \multicolumn{4}{|c|}{ Total cost of $\mathrm{A}$} & $1,150,000$ \\
\hline \multirow[t]{6}{*}{ B } & \multicolumn{5}{|c|}{ costs of Labor } \\
\hline & Planting & $\mathrm{OH}$ & 15 & 50,000 & 750,000 \\
\hline & Look after & $\mathrm{OH}$ & 10 & 50,000 & 500,000 \\
\hline & Harvest & $\mathrm{OH}$ & 5 & 50,000 & 250,000 \\
\hline & Drop off & $\mathrm{OH}$ & 10 & 50,000 & 500,000 \\
\hline & \multicolumn{4}{|l|}{ Total of B } & $2,000,000$ \\
\hline \multicolumn{2}{|c|}{ Total of $\mathrm{A}+\mathrm{B}$} & & & & $3,150,000$ \\
\hline \multicolumn{2}{|c|}{ Corn Production } & $\mathrm{Kg}$ & 3,000 & 4,000 & $12,000,000$ \\
\hline \multicolumn{2}{|c|}{ Income } & & & & $8,850,000$ \\
\hline \multicolumn{2}{|c|}{$\mathrm{R} / \mathrm{C}$} & & & & 2,810 \\
\hline
\end{tabular}

The average production volume for the three types of land is $6,750 \mathrm{~kg}$. If farmers plant hybrid maize in 1 (one) hectare of land, so they will get a total production of $6,262 \mathrm{Kg} / \mathrm{Ha}$, the selling price at that time is IDR 4,000, with this price, the farmers will get an income of IDR 22,220,000 with an average $\mathrm{R} / \mathrm{C}$ ratio average value to 4.64 . Value Production value of farming activity is the multiplication among production obtained and the selling price [8].

When viewed from the total of revenue, the cost allocation of farming costs only spent IDR 4,236,600/ha of the total income. This means that farmers get more rewards from farming activities namely IDR $15,430,000$. Thus, taking into account between the income and costs production, the Bima 20 URI maize farming is quite feasible to be developed with an average balance of $\mathrm{R} / \mathrm{C}$ of 3.561. It means that every expense of IDR 1,000 for the given input will get IDR 3,561. Corn production is determined by the use of inputs, including seeds, fertilizers, pesticides and labor and cropping systems.[9]

According to [10], costs include a measurement of the value of resources that must be sacrificed as a result of activities aimed at seeking profit.

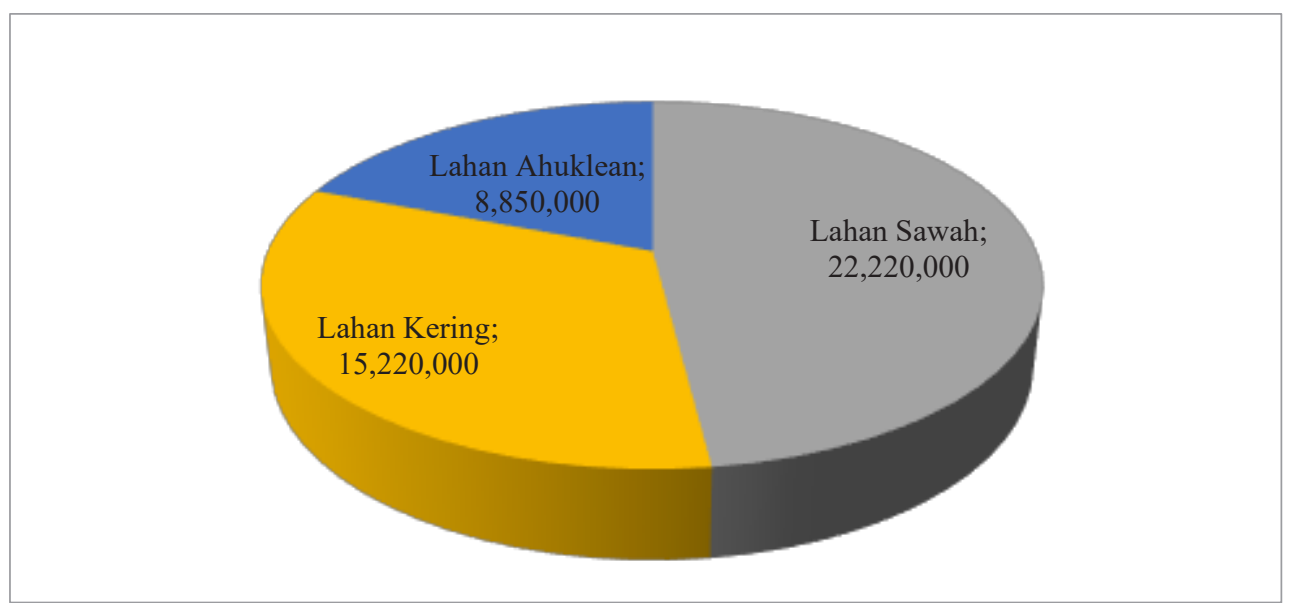

Fig.1. The average income of farming of Hibrida Corn on the three types of land 
The result of research shows that the average income of the farming of the Corn Hibrida on the three types land such as for irrigation of wet rice field IDR 22,220,000, Dry land IDR 15,220,000 and the land of Ahuklean is IDR 8,850,000. This condition describes that farmers have the stock of income, except of the main income from the result of main plant production in which is conducted[11].

\section{Conclusion}

a. Corn of Bima 20 URI has the potential to be planted as young corn, the ahuklean, can be used on land with limited irrigation;

b. Farming efforts of farmers on Hybrid Corn Bima 20 URI with the value of $\mathrm{R} / \mathrm{C}$ is more substantial than 1 such as 4.64; dry land is 3.18 and land of ahuklean is 2.81 in which can be said to feasible to be developed in the region of NTT;

c. Income of Hybrid corn farming per ha is IDR $15,430,000$, in which is a sufficient revenue contribution for the seed of business on the hybrid corn.

Acknowledgements. Thanks for Ir. Yohanes Leki Seran on his readiness as my supervisor who has given guidance and any suggestion to the writer in terms of assisting analyze and interpret data of research so that this academic writing can be published.

\section{References}

1. D. NTT, Laporan Dinas Pertanian Tanaman Pangan (2017).

2. E. F. dan M. R. Ainun Nikmah, Agriekonomika, ISSN 2301-9948 Volume 2, (2013).

3. Muh. Taufik dan Muhammad Thamrin, Penelit. Pertan. Tanam. PANGAN VOL. 28 NO, (2009).

4. S. Agustian, A. dan Friyatno, Dynamics Analysis of Demand/Consumption and Policy for National Corn Production Development (2014).

5. A. T. Bahtiar, J. sondakh, Anal. Usahatani Beberapa Var. Unggul Baru Jagung Komposit Di Sulawesi Utara Bahtiar1), 1 (2010).

6. A. G. Tahir, J. Galung Trop. 6, 1 (2017).

7. M. Mohamad, M. N. Alam, and R. A. Rauf, J. Agrol. 23, 40 (2016).

8. A. K. Zakaria, W. K. Sejati, and R. Kustiari, J. Agro Ekon. (2016).

9. M. Apriliana and M. Mustadjab, Habitat 27, 7 (2016).

10. A. Suryana and A. Agustian, Anal. Kebijak. Pertan. 12, 143 (2016).

11. A. Z. A. Purwanto, A. Muis, P. Studi, M. Agribisnis, P. Universitas, P. Studi, A. Fakultas, and P. Universitas, 22, 205 (2015). 